\title{
Folliculostellate cell interacts with pericyte via TGF $\beta 2$ in rat anterior pituitary
}

\author{
Takehiro Tsukada', Morio Azuma', Kotaro Horiguchi², Ken Fujiwara', Tom Kouki', \\ Motoshi Kikuchi ${ }^{3}$ and Takashi Yashiro' \\ 1Division of Histology and Cell Biology, Department of Anatomy, Jichi Medical University School of \\ Medicine, Tochigi, Japan \\ 2Laboratory of Anatomy and Cell Biology, Department of Health Sciences, Kyorin University, Tokyo, Japan \\ ${ }^{3}$ Laboratory of Natural History, Jichi Medical University School of Medicine, Tochigi, Japan
}

Correspondence should be addressed to T Yashiro or T Tsukada Email tyashiro@jichi.ac.jp or tsukada@jichi.ac.jp

\begin{abstract}
The anterior pituitary gland comprises five types of endocrine cells plus non-endocrine cells including folliculostellate cells, endothelial cells, and capillary mural cells (pericytes). In addition to being controlled by the hypothalamic-pituitary-target organ axis, the functions of these cells are likely regulated by local cell and extracellular matrix (ECM) interactions. However, these complex interactions are not fully understood. We investigated folliculostellate cell-mediated cell-to-cell interaction. Using S100ß-GFP transgenic rats, which express GFP in folliculostellate cells, we designed a three-dimensional cell culture to examine the effects of folliculostellate cells. Interestingly, removal of folliculostellate cells reduced collagen synthesis (Col1a1 and Col3a1). Because pericytes are important collagen-producing cells in the gland, we stained for desmin (a pericyte marker). Removal of folliculostellate cells resulted in fewer desmin-positive pericytes and less desmin mRNA. We then attempted to identify the factor mediating folliculostellate cell-pericyte interaction. RT-PCR and in situ hybridization revealed that the important profibrotic factor transforming growth factor beta-2 (TGF $\beta 2$ ) was specifically expressed in folliculostellate cells and that TGF $\beta$ receptor II was expressed in pericytes, endothelial cells, and parenchymal cells. Immunocytochemistry showed that TGF $\beta 2$ induced SMAD2 nuclear translocation in pericytes. TGF $\beta 2$ increased collagen synthesis in a dose-dependent manner. This action was completely blocked by TGF $\beta$ receptor I inhibitor (SB431542). Diminished collagen synthesis in folliculostellate cell-deficient cell aggregates was partially recovered by TGF $\beta 2$. TGF $\beta 2$-mediated folliculostellate cell-pericyte interaction appears to be essential for collagen synthesis in rat anterior pituitary. This finding sheds new light on local cell-ECM interactions in the gland.
\end{abstract}

\section{Key Words}

- pituitary

- folliculostellate cell

- TGF $\beta$

- collagen

- three-dimensional cell culture

\section{Introduction}

Each cellular function is controlled by systemic regulators (endocrine, nerve, and immune systems) and local regulators. The latter include paracrine and autocrine factors and extracellular matrix (ECM) and are important in tissue formation, homeostasis, and regeneration (Hwang et al. 2009). The ECM is a composite of fibers,

Published by Bioscientifica Ltd 
adhesive glycoproteins, glycosaminoglycans, and other soluble proteins. These molecules are partially responsible for the mechanical properties of tissues and cell functions. The collagens are the most abundant ECM in the body and comprise more than 20 types. Type I and III collagens form insoluble fibers that define tissue stiffness and tensile strength. The fibrillar collagens also affect cellular functions such as cell morphology, migration, and proliferation (see the report by Gelse et al. 2003 for more information). The collagens are also important in providing these biophysical and biological characteristics to tissues and cells in the anterior pituitary gland.

Our group has identified various collagen types (type I, III, IV, and VI collagens) in rat anterior pituitary gland (Kaidzu et al. 2000). These collagens are distributed around endocrine cells and capillaries and support tissue structure. With respect to function, type I and/or type III collagens act on anterior pituitary cells to modulate hormone and ECM production (Kuchenbauer et al. 2001, Syaidah et al. 2013) and alter cellular behaviors (Toral et al. 2007, Horiguchi et al. 2010). It is generally accepted that fibroblasts and myofibroblasts are collagen-producing cells in many tissues; however, these cells have not been identified in the anterior pituitary gland. Recently, we investigated tissue-specific collagen-producing cells in rat anterior pituitary gland and found that desmin-immunopositive cells around capillaries, namely pericytes, produce collagen (Fujiwara et al. 2010). Although the importance of collagens as a local regulator has been suggested, the regulatory mechanism underlying collagen synthesis in pericytes has not been studied.

The anterior pituitary gland has five types of endocrine cells plus folliculostellate cells, which do not produce adenohypophysial hormones. Folliculostellate cells are believed to act as stem/progenitor cells or phagocytes or to regulate hormone release (Inoue et al. 1999, Allaerts \& Vankelecom 2005). This study designed a three-dimensional (3D) cell culture of rat anterior pituitary cells in the presence and absence of folliculostellate cells and investigated folliculostellate cell-mediated cell-to-cell interaction. Interestingly, we observed a novel cell-to-cell interaction between folliculostellate cells and pericytes in the gland and found that transforming growth factorbeta-2 (TGF 2 ) acts as a mediator that promotes collagen synthesis in pericytes.

\section{Materials and methods}

\section{Animals}

Wistar rats were purchased from Japan SLC (Shizuoka, Japan). The S100 $\beta$-green fluorescent protein (GFP) transgenic Wistar-crlj stain (S100 $\beta$-GFP) of rat was produced by integrating the reporter gene GFP driven by the rat S100 $\beta$ promoter (Itakura et al. 2007) and was bred in our laboratory. Male rats of $8-10$ weeks old weighing 250-300 g were used. Animals were given ad libitum access to food and water and were maintained at $22^{\circ} \mathrm{C}$ under a $12 \mathrm{~h}$ light: $12 \mathrm{~h}$ darkness cycle. All animal experiments were carried out in a humane manner after receiving approval from the Institutional Animal Experiment Committee of Jichi Medical University and were conducted in accordance with the Institutional Regulations for Animal Experiments and Fundamental Guidelines for Proper Conduct of Animal Experiments and Related Activities in Academic Research Institutions, under the jurisdiction of the Japanese Ministry of Education, Culture, Sports, Science and Technology.

\section{Cell sorting}

After deep anesthesia was induced with intraperitoneally injected pentobarbital sodium (Kyoritsu Seiyaku, Tokyo, Japan), 10-20 anterior pituitary glands were excised from S100ß-GFP transgenic rats, after which anterior pituitary cells (approximately $1.0-1.5 \times 10^{6}$ cells/gland) were isolated, as described previously (Horiguchi et al. 2008). The isolated cells were separated into GFP-positive cells (folliculostellate cells) and GFP-negative cells using a MoFlo XDP cell sorter (Beckman Coulter, Brea, CA, USA). About $1.0-2.0 \times 10^{4}$ and $1.0-2.0 \times 10^{5}$ cells/gland were collected for the GFP-positive and GFP-negative fractions respectively. The GFP-positive and GFP-negative cells were then processed for hanging drop 3D cell culture and reverse transcription polymerase chain reaction (RT-PCR) analysis (see below).

\section{Hanging drop 3D cell culture}

GFP-positive and GFP-negative cells, or isolated anterior pituitary cells from Wistar rats, were resuspended in cell culture media containing Medium 199 with Earle's salts (Life Technologies) supplemented with $10 \%$ fetal bovine serum (Sigma-Aldrich), $0.5 \mathrm{U} / \mathrm{mL}$ penicillin, and $0.5 \mu \mathrm{g} / \mathrm{mL}$ streptomycin (Life Technologies). The hanging drop method was used for 3D cell culture, as described previously (Tsukada et al. 2013). Briefly, a $25 \mu \mathrm{L}$ drop containing 5000 cells was placed on the undersurface of $100 \mathrm{~mm}$ Petri dish lids, which were then cultured over sterile phosphate buffer saline (PBS) at $37^{\circ} \mathrm{C}$ in a humidified incubator with $5 \% \mathrm{CO}_{2}$. Regarding the GFP-positive and

Published by Bioscientifica Ltd 
GFP-negative cells, the cells were mixed at a proportion of $0 \%$ GFP-positive cells (without folliculostellate cells) or 5\% GFP-positive cells (with folliculostellate cells, a proportion of $5-10 \%$ folliculostellate cells is equivalent to that in normal adult rat anterior pituitary (Hosoya \& Watanabe 1997, Perez-Castro et al. 2012)) and then cultured in hanging drops. The resulting cell aggregates were processed for each experiment (see below). We previously confirmed that an in vivo-like folliculostellate cell meshwork and type I and III collagens had formed 5 days after plating (Tsukada et al. 2013). An IX71 inverted fluorescence microscope (Olympus) was used for observation of cell aggregates.

\section{Transmission electron microscopy}

After 5 days of 3D cell culture, 50-100 cell aggregates were collected in a $1.5 \mathrm{~mL}$ tube and centrifuged at $200 \mathrm{~g}$ for $5 \mathrm{~min}$ at room temperature. The pellets were immediately fixed with $2.5 \%$ glutaraldehyde (Merck) in $10 \mathrm{mM}$ phosphate buffer $(\mathrm{PB})$ for $2 \mathrm{~h}$. After washing in $\mathrm{PB}$, the samples were postfixed in ice-cold $1 \% \mathrm{OsO}_{4}$ in $\mathrm{PB}$ for $90 \mathrm{~min}$. The samples were then dehydrated in an ethanol series and embedded in Quetol 812 epoxy resin (Nissin EM, Tokyo, Japan). Ultrathin sections were prepared, stained with $2 \%$ uranyl acetate and lead citrate, and then observed using an HT7700 transmission electron microscope (Hitachi).

\section{Immunofluorescence microscopy}

Around 20-30 cell aggregates were mounted on an MAScoated glass slide (Matsunami Glass, Osaka, Japan) and immediately fixed with ice-cold $4 \%$ paraformaldehyde (PFA) in $50 \mathrm{mM} \mathrm{PB}(\mathrm{pH} \mathrm{7.4)}$ for $3 \mathrm{~h}$. The cells were permeabilized in PBS containing $0.2 \%$ Triton X-100 (Sigma-Aldrich) for $20 \mathrm{~min}$ at room temperature and then incubated in blocking solution ( $2 \%$ normal goat serum in PBS) for $30 \mathrm{~min}$ at room temperature, after which they were incubated with primary antibodies for $90 \mathrm{~min}$ at $30^{\circ} \mathrm{C}$. The primary antibodies included rabbit polyclonal anti-type I and anti-type III collagen and anti-desmin antibodies (see Table 1 for information on primary antibodies). The cells were then incubated with Alexa Fluor 568-conjugated goat anti-rabbit IgG (1:200; Life Technologies) in PBS for $30 \mathrm{~min}$ at $30^{\circ} \mathrm{C}$. Cover slips were mounted onto the cells using Vectashield mounting medium containing 4',6-diamidino-2phenylindole (DAPI; Vector Laboratories). Stained cells or GFP-expressing folliculostellate cells were subsequently analyzed with an FV1000 confocal laser microscope (Olympus). Images were processed for presentation using Photoshop CS5 (Adobe Systems). The absence of an observable nonspecific reaction was confirmed using normal rabbit serum.

\section{In situ hybridization}

After anesthesia, Wistar rats were perfused through the left ventricle with ice-cold $4 \%$ PFA in $50 \mathrm{mM} \mathrm{PB} \mathrm{(pH} \mathrm{7.4)} \mathrm{for}$ 5 min. Pituitary glands were then excised and immersed in the same fixative for $24 \mathrm{~h}$ at $4^{\circ} \mathrm{C}$, after which the tissues were immersed for 2 days in $50 \mathrm{mM} \mathrm{PB}$ (pH 7.2) containing $30 \%$ sucrose at $4^{\circ} \mathrm{C}$. The tissues were then embedded in Tissue-Tek OCT compound (Sakura Finetechnical, Tokyo, Japan), and frozen sections $(8 \mu \mathrm{m})$ were obtained using a cryostat (CM3000, Leica Microsystems, Wetzlar, Germany). In situ hybridization was performed with digoxigenin (DIG)-labeled cRNA probes, as described in our previous report (Fujiwara et al. 2007a). The following DNA fragments of rat TGF $\beta 2$ (NM_031131) and TGF $\beta$ receptor II (NM_031132) were amplified from rat pituitary cDNA by PCR (see Table 2 for primer information). Amplified cDNA fragments were ligated into the pGEM-T vector (Promega) and cloned. Gene-specific antisense or

Table 1 Information on primary antibodies used.

\begin{tabular}{|c|c|c|}
\hline Antibody & Type & Dilution \\
\hline Type I collagen & Rabbit polyclonal & $1: 1000$ \\
\hline Type II collagen & Rabbit polyclonal & $1: 1500$ \\
\hline Desmin & Rabbit polyclonal & $1: 1000$ \\
\hline Desmin & Mouse monoclonal & $1: 50$ \\
\hline S100 & Rabbit monoclonal & 1:1000 \\
\hline SMAD2 & Rabbit monoclonal & $1: 200$ \\
\hline
\end{tabular}

\begin{tabular}{l}
$\begin{array}{l}\text { References for validation } \\
\text { of antibodies used }\end{array}$ \\
\hline Hagiwara et al. (2010) \\
Hagiwara et al. (2010) \\
Azuma et al. (2015) \\
Hamzah et al. (2008) \\
Azuma et al. (2015) \\
Narimatsu et al. (2015)
\end{tabular}

\begin{tabular}{l}
$\begin{array}{l}\text { Source; Catalog } \\
\text { number }\end{array}$ \\
\hline LSL; LS-1102 \\
LSL; LS-1393 \\
Abcam; ab15200 \\
DAKO; Clone D33 \\
DAKO; S100 \\
Cell Signaling \\
Technology; 5339S \\
\hline
\end{tabular}


sense DIG-labeled cRNA probes were generated using the Roche DIG RNA labeling kit (Roche Diagnostics). DIGlabeled cRNA probe hybridization was performed at $55^{\circ} \mathrm{C}$ for $16 \mathrm{~h}$. Detection of each type of mRNA was performed with alkaline phosphatase-conjugated anti-DIG antibody (Roche Diagnostics) using 4-nitroblue tetrazolium chloride (NBT) and 5-bromo-4-chloro-3-indolyl phosphate (BCIP, Roche Diagnostics). In a control experiment, no specific signal was detected in sections processed with the DIG-labeled sense RNA probes.

For doublestaining, subsequent immunohistochemistry was performed as described previously (Fujiwara et al. 2007b). The sections were incubated with rabbit polyclonal anti-S100 protein or desmin antibody (Table 1) for $90 \mathrm{~min}$ at $30^{\circ} \mathrm{C}$ and then with biotinylated antirabbit IgG (Vector Laboratories) for $30 \mathrm{~min}$ at $30^{\circ} \mathrm{C}$. The immunoreactive signal was detected by the Vectastain $\mathrm{ABC}$ system (Vector Laboratories) and 3,3'-diaminobenzidine (Dojindo Laboratories, Kumamoto, Japan). The absence of an observable nonspecific reaction was confirmed using normal rabbit serum.

\section{RT-PCR}

After cell sorting, total RNA was extracted from GFPpositive cells (approximately $3.0-5.0 \times 10^{5}$ cells/extraction) and GFP-negative cells (approximately 1.0-2.0 × $10^{6}$ cells/ extraction) using an RNeasy mini kit and an RNase-free DNase set according to the manufacturer's instructions (Qiagen). cDNA was synthesized using the PrimeScript RT reagent kit (Takara Bio) with oligo-(dT) 20 primer (Life Technologies). cDNAs were mixed with gene-specific primers (Table 2), Blend Taq DNA polymerase, buffer, and dNTPs according to the manufacturer's instructions (TOYOBO, Osaka, Japan) and then subjected to $2 \mathrm{~min}$ at $94^{\circ} \mathrm{C}, 26-30$ cycles of $30 \mathrm{~s}$ at $94^{\circ} \mathrm{C}, 30 \mathrm{~s}$ at $58^{\circ} \mathrm{C}, 30 \mathrm{~s}$ at $72^{\circ} \mathrm{C}$, and an additional $7 \mathrm{~min}$ at $72^{\circ} \mathrm{C}$ in a GeneAmp PCR System 9700 (Applied Biosystems). The products were run on $1.5 \%$ agarose gels and visualized with ethidium bromide.

\section{Treatment of TGF $\beta 2$ and TGF $\beta$ receptor linhibitor (SB431542)}

Synthetic human TGF $\beta 2$ (PeproTech, Rocky Hill, NJ, USA) and selective TGF $\beta$ receptor I inhibitor (SB431542: Merck Millipore) were diluted in Hanks' balanced salt solution (Life Technologies) containing $0.1 \%$ bovine serum albumin (BSA) and dimethyl sulfoxide (DMSO), respectively, and stored at $-20^{\circ} \mathrm{C}$ until use. For $24-\mathrm{h}$ treatment, $120-150$ anterior pituitary cell aggregates from Wistar rats were collected in a $15 \mathrm{~mL}$ tube 4 days after 3D cell culture and then centrifuged at $200 \boldsymbol{g}$ for $2 \mathrm{~min}$. Cell culture media were replaced with $470 \mu \mathrm{L}$ of fresh cell culture

Table 2 Primers for RT-PCR, real-time PCR, and CRNA probes.

\begin{tabular}{|c|c|c|c|c|c|c|}
\hline Gene name & Symbol & $\begin{array}{l}\text { GenBank Acc. } \\
\text { number }\end{array}$ & Forward sequence $\left(5^{\prime}-3^{\prime}\right)$ & Reverse sequence $\left(5^{\prime}-3^{\prime}\right)$ & Size (bp) & Use \\
\hline Type I collagen & Col1a1 & NM_053304 & ACCCCAAGGAGAAGAAGCAT & GGTCAGCTGGATAGCGACAT & 110 & Real-time PCR \\
\hline Type III collagen & Col3a 1 & NM_032085 & GGCTGCAAGATGGATGCTAT & ATCTGTCCACCAGTGCTTCC & 105 & Real-time PCR \\
\hline Desmin & Des & NM_022531 & CGAGCTCTACGAGGAGGAGA & GCCTCTGCAGGTCGTCTATC & 113 & Real-time PCR \\
\hline TGF $\beta 1$ & Tgfb1 & NM_021578 & GACTCTCCACCTGCAAGACC & GTTTGGGACTGATCCCATTG & 642 & RT-PCR \\
\hline \multirow[t]{2}{*}{ TGF $\beta 2$} & $\operatorname{Tgfb2}$ & NM_031131 & АСTCTACCTGACCCGCTCTG & GCGGACGATTCTGAAGTAGG & 570 & RT-PCR \\
\hline & & & AAGCCAGGATGAAAATCACG & AAGCAGGTCACCATTTCACC & 852 & cRNA probe \\
\hline TGF $\beta 3$ & Tgfb3 & NM_013174 & GAAGGCTGCACTCAGGAAAC & GCAGTTCTCCTCCAAGTTGC & 681 & RT-PCR \\
\hline TGF $\beta$ receptor-I & Tgfbr1 & NM_012775 & ACCTTCTGATCCATCCGTTG & AACACCAGTGGTTCGGAGTC & 615 & RT-PCR \\
\hline \multirow[t]{2}{*}{ TGF $\beta$ receptor-II } & Tgfbr2 & NM_031132 & TCACTAGGCACGTCATCAGC & ATCTGGGTGCTCCAGTTCAC & 626 & RT-PCR \\
\hline & & & GGCGAGACCTTCTTCATGTG & TGTCCTTCTCCGTTTTCCAC & 490 & cRNA probe \\
\hline TGF $\beta$ receptor-III & Tgfbr3 & NM_017256 & TACTCCCACACAGGGGAGAC & AGGAATGTTGCGGTGGTAAG & 681 & RT-PCR \\
\hline \multirow[t]{2}{*}{$\mathrm{S} 100 \beta$} & $S 100 b$ & NM_013191 & ATAGCACCTCCGTTGGACAG & CATCTCAGTGGCCCTTCATT & 527 & RT-PCR \\
\hline & & & ATAGCACCTCCGTTGGACAG & TCGTTTGCACAGAGGACAAG & 132 & Real-time PCR \\
\hline$\beta$-actin & Actb & NM_031144 & $\begin{array}{l}\text { TGGCACCACACTTTCTACAAT- } \\
\text { GAGC }\end{array}$ & GGGTCATCTTTTCACGGTTGG & 106 & $\begin{array}{l}\text { RT-PCR, } \\
\text { real-time PCR }\end{array}$ \\
\hline $\begin{array}{l}\text { http://jo } \\
\text { DOI: } 10 .\end{array}$ & & & Printed in Great Britain & & & \\
\hline
\end{tabular}


media, and all cell aggregates were replated onto a 24-well plastic plate. To obtain the indicated concentrations, $30 \mu \mathrm{L}$ of TGF $\beta 2$ and/or SB431542 diluted by cell culture media was added to the well (final volume, $500 \mu \mathrm{L}$ ). The cell aggregates were incubated for an additional $24 \mathrm{~h}$ at $37^{\circ} \mathrm{C}$ in a humidified incubator with $5 \% \mathrm{CO}_{2}$. BSA (0.1\%) and DMSO were diluted in the same manner and used as vehicle controls for TGF $\beta 2$ and SB431542 respectively.

For the 5-day treatment, anterior pituitary cells from Wistar rats and GFP-negative cells from S100 $\beta$-GFP transgenic rats were resuspended in media containing TGF 22 and SB431542 at the indicated concentrations respectively. The cells were cultured in hanging drops (120-150 drops/treatment) for 5 days at $37^{\circ} \mathrm{C}$ in a humidified incubator with $5 \% \mathrm{CO}_{2}$.

\section{SMAD2 nuclear translocalization analysis}

Isolated anterior pituitary cells from Wistar rats were plated onto eight-well glass chamber slides $\left(1 \mathrm{~cm}^{2} /\right.$ well; Nalge Nunc Int., Rochester, NY, USA) at a density of $4 \times 10^{5}$ cells $/ \mathrm{cm}^{2}$ in $400 \mu \mathrm{L}$ cell culture media and incubated for 3 days at $37^{\circ} \mathrm{C}$ in a humidified incubator with 5\% $\mathrm{CO}_{2}$. After a 30 -min treatment with TGF $\beta 2(50 \mathrm{ng} / \mathrm{mL})$ or BSA, the cells were fixed in $4 \%$ PFA in $25 \mathrm{mM}$ of $\mathrm{PB}(\mathrm{pH}$ 7.4) for $20 \mathrm{~min}$ at room temperature. After permeabilization and blocking (see above), the cells were incubated with rabbit monoclonal anti-SMAD2 and mouse monoclonal anti-desmin antibodies (Table 1) for $90 \mathrm{~min}$ at $30^{\circ} \mathrm{C}$, followed by Alexa Fluor 488-conjugated goat anti-rabbit IgG (1:200, Life Technologies) and Alexa Fluor 568-conjugated goat anti-mouse IgG (1:200; Life Technologies) for $30 \mathrm{~min}$ at $30^{\circ} \mathrm{C}$. Stained cells were mounted with DAPI and analyzed as described above. The absence of an observable nonspecific reaction was confirmed using normal rabbit and mouse sera.

\section{Real-time PCR quantification of mRNA levels}

After treatment with synthetic TGF $\beta$ and/or SB431542, total RNA from cell aggregates was extracted, and cDNA was synthesized as described above. Quantitative real-time PCR (ABI PRISM 7900HT; Applied Biosystems) was performed using gene-specific primers (Table 2) and SYBR Premix Ex Taq (Takara Bio) containing SYBR Green I. For normalization, $\beta$-actin (Actb: NM_031144) was quantified. All measurements were made in duplicate, and relative quantification was conducted using the standard curve method.

\section{Statistical analysis}

All results are presented as mean \pm S.E.M. The unpaired Student's $t$-test for two-group comparison or one-way analysis of variance (ANOVA) followed by Dunnett's test for multiple comparisons was performed using Prism version 6 (GraphPad Software). A $P$ value $<0.05$ was considered to indicate statistical significance.

\section{Results}

Folliculostellate cell-pericyte interaction in collagen synthesis

Effects of the absence of folliculostellate cells on cell aggregate formation Dispersed anterior pituitary cells from S100ß-GFP rats were cultured with and without folliculostellate cells in hanging drops for 5 days, after which the resulting cell aggregates were examined by light microscopy (Fig. 1A). The aggregates containing folliculostellate cells had a round/oval shape with a smooth outer layer (Fig. 1Aa). In the absence of folliculostellate cells, the aggregates had an irregular shape, and the fringe of aggregates was not smooth (Fig. 1Ab). These morphological differences in cell aggregate formation were also observed in our previous study (Tsukada et al. 2014). Transmission electron microscopy was then performed to compare the morphological characteristics of aggregates with and without folliculostellate cells (Fig. 1B). In the aggregate with folliculostellate cells, fibrillar collagen with a periodic striation pattern was observed in the extracellular space (Fig. 1Ba and inset). In contrast, no extracellular structure was observed in the folliculostellate cell-deficient cell aggregates (Fig. 1Bb).

Effect of the absence of folliculostellate cells on collagen deposition and synthesis The major fibrillar collagens are the type I and type III collagens. We therefore stained the aggregates with isoform-specific anticollagen antibodies (Fig. 2A). Although both type I and III collagens were observed in the presence of folliculostellate cells, type III collagen was predominant (Fig. 2Aa and c). Type III collagen was deposited throughout almost the entire extracellular space and exhibited a fibrillar structure. In the absence of folliculostellate cells, neither type I nor III collagen was detected (Fig. 2Ab and d). Consistent with these results, the gene expressions of type I and III collagens (gene symbols Col1a1 and Col3a1 respectively) were significantly lower in the absence of folliculostellate cells (Fig. 2B).

Published by Bioscientifica Ltd 
A
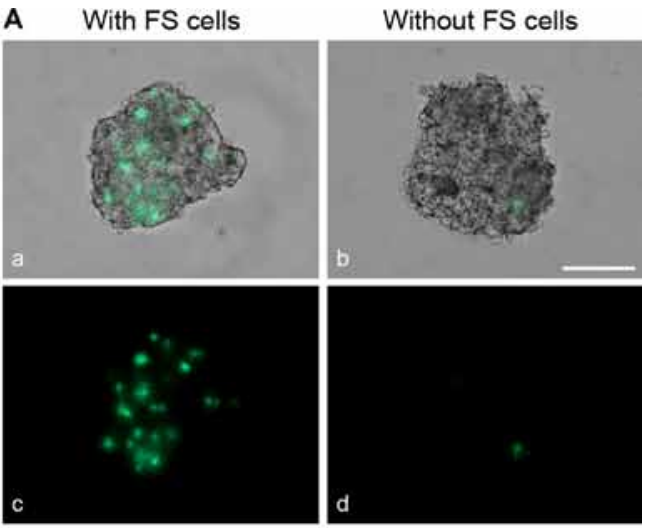

B

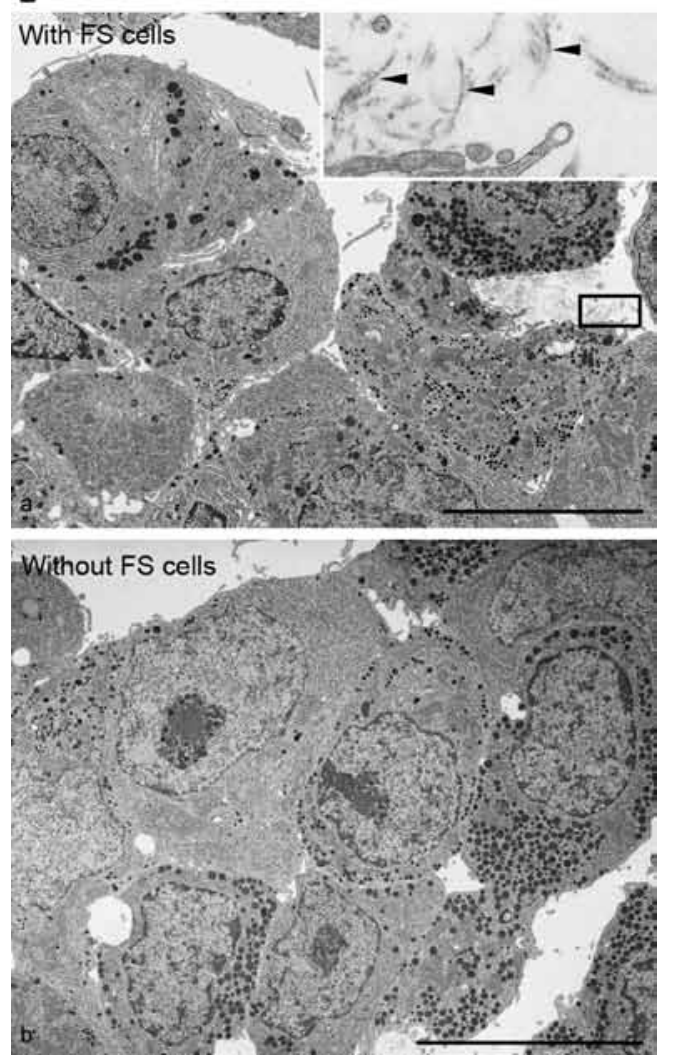

Figure 1

(A) Anterior pituitary cell aggregates with and without folliculostellate (FS) cells in hanging drop 3D cell culture. Anterior pituitary cells of S100 $\beta$-GFP transgenic rats were used. The top panels are phase-contrast images of cell aggregates superimposed on fluorescence images of GFP-expressing folliculostellate cells $(a, b)$. The bottom panels show folliculostellate cells (c, d). As in our previous study (Tsukada et al. 2014), cells formed round/oval aggregates with a smooth outer layer in the presence of folliculostellate cells (a); however, the fringe of folliculostellate cell-deficient cell aggregates was not smooth (b). Scale bar: $100 \mu \mathrm{m}$. (B) Electron micrographs of cell aggregates with and without folliculostellate cells. In the presence of folliculostellate cells (a), insoluble fibrillar architectures were observed in the extracellular space. The inset shows a magnified view of boxed area. The fibers had periodic striations, indicating deposition of fibrillar collagens (arrowheads). However, no fiber was observed in the aggregates without folliculostellate cells (b). Scale bars: $10 \mu \mathrm{m}$.
A
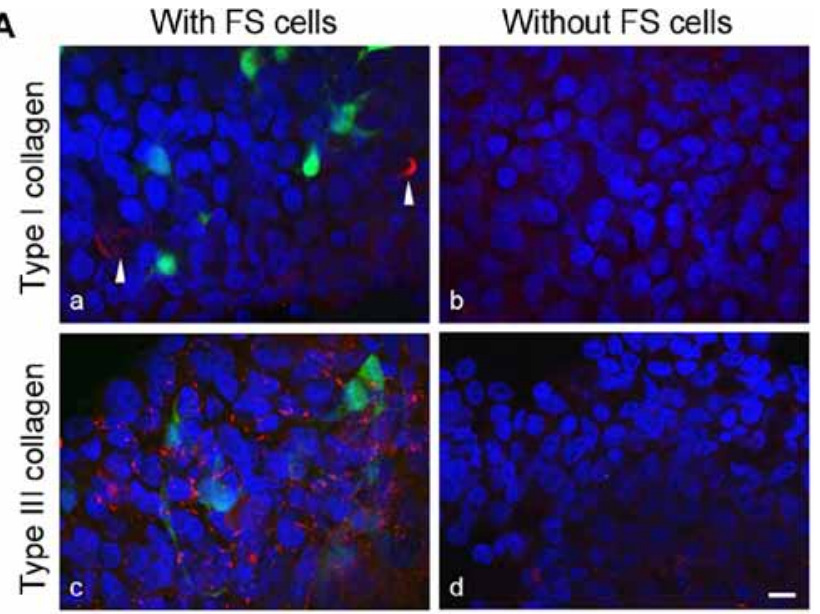

B

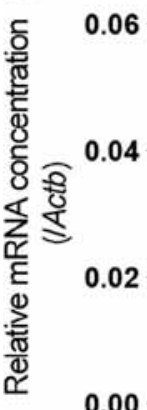

Col1a1

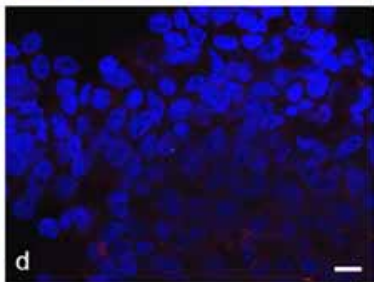

d

Col3a1

0.00

$\begin{array}{cccc}\text { With } & \text { Without } & \text { With } & \text { Without } \\ \text { FS cells } & \text { FS cells } & \text { FS cells } & \text { FS cells }\end{array}$

Figure 2

(A) Immunofluorescence of type I and III collagens. Anterior pituitary cells of S100 $\beta$-GFP transgenic rats were used. Cell aggregates with folliculostellate (FS) cells (a, c) and without folliculostellate cells (b, d) were stained with anti-type I $(a, b)$ and anti-type III collagen antibodies (c, d). Collagens, GFP-expressing folliculostellate cells, and nuclei are shown in red, green, and blue respectively. In the presence of folliculostellate cells, type I collagen deposition was scarce (a, arrowheads), whereas type III collagen deposition was clearly observed (c). However, no collagen deposition was detected in the absence of folliculostellate cells $(b, d)$. Scale bar: $10 \mu \mathrm{m}$. (B) Relative mRNA concentration of type I and III collagens (Co/1a1 and Col3a1 respectively) was evaluated by quantitative real-time PCR. Gray and white bars represent cell aggregates with and without folliculostellate cells respectively ( $n=7$, mean \pm S.E.M.). Concentrations were normalized with $\beta$-actin (Actb) mRNA concentration. Col1a1 and Col3a1 expressions were lower in the absence of folliculostellate cells. ${ }^{*} P<0.05$ (Student's $t$-test).

\section{Effect of the absence of folliculostellate cells on collagen-producing cells Our previous reports} showed that pericytes, but not folliculostellatecells, produce type I and type III collagens in rat anterior pituitary gland (Fujiwara et al. 2010, Jindatip et al. 2013). To examine whether removal of folliculostellate cells affects collagen-producing cells, cell aggregates were

Published by Bioscientifica Ltd 
stained for desmin, a pericyte marker. Pericytes were detectable in cell aggregates with and without folliculostellate cells (Fig. 3A); however, the number of pericytes was less in the absence of folliculostellate cells. To confirm the staining results, we performed real-time PCR (Fig. 3B), which showed that desmin expression was lower in the absence of folliculostellate cells.

\section{Folliculostellate cell-pericyte interaction via TGF $\beta 2$}

Expression and localization of TGF $\beta$ isoforms and TGF $\beta$ receptors To determine whether folliculostellate cells secrete a factor that acts on pericytes and promotes collagen production, we examined expression of the major profibrotic cytokine TGF $\beta$ in folliculostellate cells. Among the three TGF $\beta$ isoforms (gene symbols $T g f b 1-3$ ), $T g f b 2$ was exclusively expressed in GFP-positive cells (folliculostellate cells), whereas $T g f b 1$ andTgfb3 were expressed in GFP-positive and GFP-negative cells (Fig. 4). $T g f b 1$ expression was predominant in GFP-negative cells, and $T g f b 3$ expression was similar in GFP-positive and GFP-negative cells. Expressions of TGF $\beta$ receptor I and II (gene symbols Tgfbr1 and Tgfbr2), which form a heteromeric complex, were higher in GFP-negative cells than in GFP-positive cells, whereas TGF $\beta$ receptor III (gene symbol $T g f b r 3$ ) was undetectable in GFP-positive and GFP-negative cells (Fig. 4). In situ hybridization showed that $T g f b 2$ - and Tgfbr2-expressing cells were present in anterior pituitary gland (Fig. $5 \mathrm{~b}$ and d). $T g f b 2$-expressing cells formed a cell cluster in parenchymal cells and were costained with S100 protein (folliculostellate cell marker; Fig. 5c). In contrast, $T g f b r 2$-expressing cells were detected in parenchymal cells, endothelial cells, and perivascular cells (Fig. $5 \mathrm{~d}$ and e). Tgfbr2-expressing perivascular cells were stained for desmin (pericytes, Fig. 5e). Next, we investigated the nuclear localization of SMAD2 protein in pericytes to determine whether TGF $\beta$ receptors in pericytes are functional. After 30-min treatment of synthetic TGF $\beta 2$ in anterior pituitary cells, SMAD2 was intensely stained in the nuclei of desmin-immunopositive cells (Fig. 6e and f) but diffusely stained in cytoplasm treated with vehicle (Fig. 6B and C).

\section{Effect of TGFB2 and TGF $\beta$ receptor I inhibitor} (SB431542) on collagen synthesis Anterior pituitary cell clusters from Wistar rats were treated with TGF $\beta 2$ for $24 \mathrm{~h}$, and Col1a1 and Col3a1 expressions were examined by real-time PCR (Fig. 7). TGF $\beta 2$ significantly increased Col1a1 and Col3a1 expressions in a dose-dependent manner
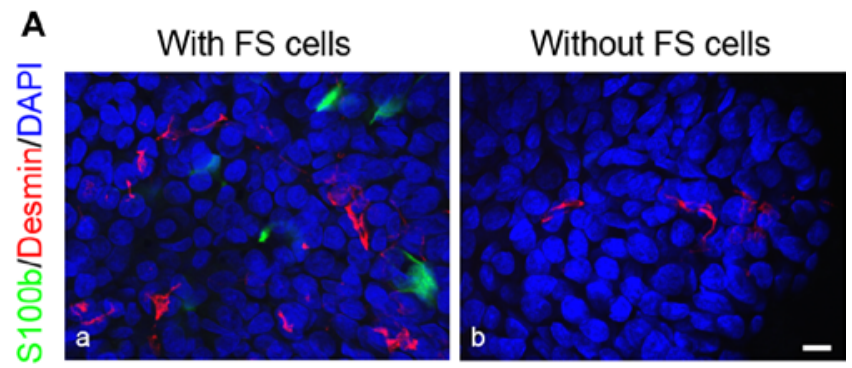

B

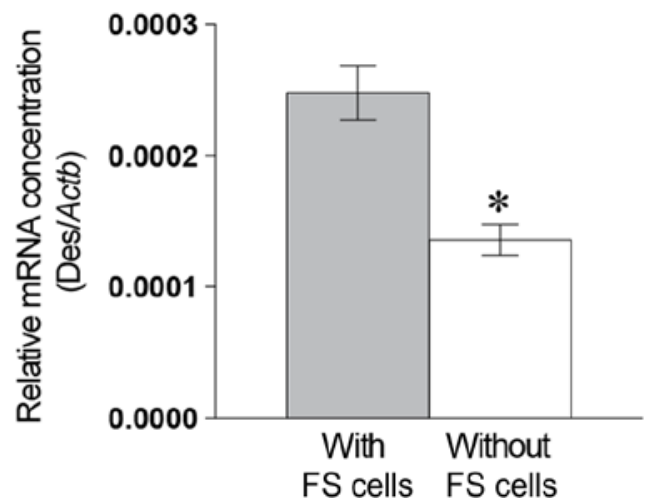

Figure 3

(A) Immunofluorescence of desmin. Anterior pituitary cells of S100 $\beta$-GFP transgenic rats were used. Cell aggregates with folliculostellate (FS) cells (a) and without folliculostellate cells (b) were stained with anti-desmin antibody. Desmin, GFP-expressing folliculostellate cells, and nuclei are shown in red, green, and blue respectively. In the presence of folliculostellate cells, desmin-immunopositive cells (pericytes) were scattered in the cell aggregate; however, desmin-immunopositive cells were scarce in the absence of folliculostellate cells (b). Scale bar: $10 \mu \mathrm{m}$. (B) Relative mRNA concentration of desmin (Des) was evaluated by quantitative real-time PCR. Gray and white bars represent cell aggregates with and without folliculostellate cells respectively ( $n=8$, mean \pm S.E.M.). Concentrations were normalized with $\beta$-actin (Actb) mRNA concentration. Desmin expressions were lower in the absence of folliculostellate cells. ${ }^{*} P<0.05$ (Student's $t$-test).

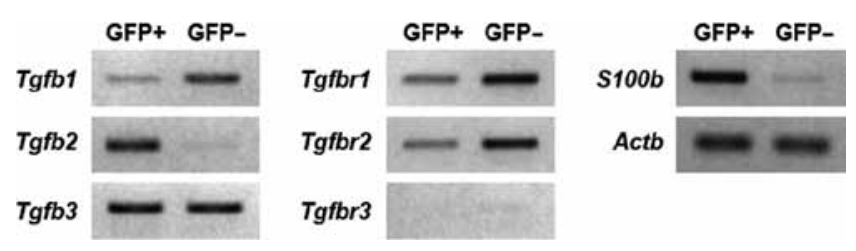

Figure 4

Expression of TGF $\beta$ isoforms and TGF $\beta$ receptors in GFP-positive and GFP-negative cells. GFP-positive (GFP+: folliculostellate cell) and GFP-negative fraction (GFP-: other cell types) were obtained by cell sorting of $\mathrm{S} 100 \beta-\mathrm{GFP}$ rat anterior pituitary cells, and expressions of TGF $\beta$ 1-3 (Tgfb1-3) and TGF $\beta$ receptors I-III (Tgfbr1-3) in each fraction were determined by RT-PCR (30 cycles). Tgfb2 was expressed only in folliculostellate cells. Expressions of the heteromeric TGF $\beta$ receptors, Tgfbr1 and Tgfbr2, were predominant in GFP-negative cells. S100 $\beta$ (S100b, 28 cycles) and $\beta$-actin (Actb, 26 cycles) were used as the folliculostellate cell marker and internal control respectively.
() 2016 Society for Endocrinology Printed in Great Britain 

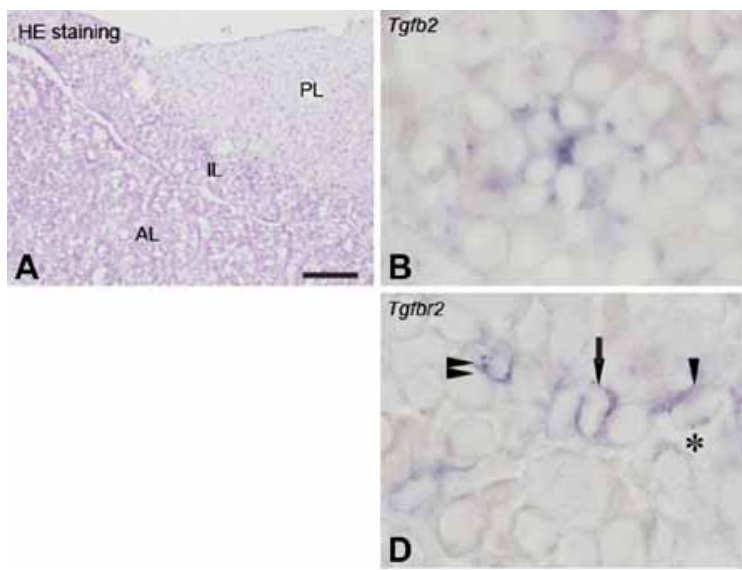

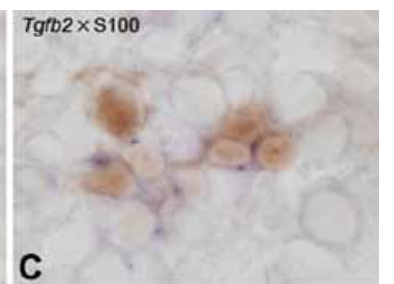

Tgtbr $2 \times$ desmin
Figure 5

Localization and identification of cells expressing TGF $\beta 2$ and TGF $\beta$ receptor II in the anterior pituitary of Wistar rats. Hematoxylin and eosin (HE) staining, TGF $\beta 2$ in situ hybridization, and double staining of TGF $\beta 2$ in situ hybridization and S100 immunohistochemistry are shown in $\mathrm{a}, \mathrm{b}$, and c respectively (purple: TGF $\beta 2$; brown: $\mathrm{S100}$ ). TGF $\beta 2$-expressing cells were detected in anterior lobe (b, AL) and costained with S100 (c). TGF $\beta$ receptor II in situ hybridization and double staining of TGF $\beta$ receptor II in situ hybridization and desmin immunohistochemistry are shown in $d$ and e respectively (purple: TGF $\beta$ receptor $\mathrm{Il}$; brown: desmin). TGF $\beta$ receptor II-expressing cells were detected in parenchymal cells (double arrowhead), perivascular cells (arrow), and capillary endothelial cells (arrowhead) in AL (d). Perivascular cells expressing TGF $\beta$ receptor II were costained with desmin (e, arrow). *capillary lumen, IL, intermediate lobe; PL, posterior lobe. Scale bars: $100 \mu \mathrm{m}$ (a), $10 \mu \mathrm{m}$ (b-e).
(Fig. 7A). In contrast, a 5-day treatment of TGF $\beta$ receptor I inhibitor significantly decreased Col3a1 expression in a dose-dependent manner (Fig. 7B). Although TGF $\beta$ receptor I inhibitor tended to decrease Col1a1 expression, the difference was not significant (Fig. 7B). TGF 32 -induced Col1a1 and Col3a1 expressions were completely abolished by co-administration with TGF $\beta$ receptor I inhibitor (Fig. 7C). When the folliculostellate cell-deficient cell aggregates were treated with TGF $\beta 2$ for 5 days, Col1a1 and Col3a1 expressions (which were reduced by removal of folliculostellate cells) were partially rescued (Fig. 8).

\section{Discussion}

This study using a 3D culture system highlights the importance of folliculostellate cells in collagen synthesis. Our previous study showed that 3D cell aggregate exhibited (1) highly elongated folliculostellate cells,
(2) complex folliculostellate cell meshwork formation, and (3) dense collagen fiber deposition, all of which were observed in anterior pituitary in vivo (Tsukada et al. 2013). Because such in vivo-like cell and ECM architectures are not observed in conventional two-dimensional (2D) culture, the 3D culture system has the potential to elucidate cellular and molecular functions that cannot be adequately investigated by conventional 2D culture.

Type I and III collagens are important fibrillar collagens in rat anterior pituitary gland (Kaidzu et al. 2000). Several effects of collagen have been reported. Type I collagen decreases ACTH biosynthesis and inhibits proliferation of AtT-20 corticotroph tumor cells (Kuchenbauer et al. 2001). This study showed that cell aggregates without folliculostellate cells had less mRNA for type I and III collagens and no collagen deposition (Figs $1 \mathrm{~B}$ and 2). This is the first report that folliculostellate cells are indispensable in collagen synthesis and deposition.

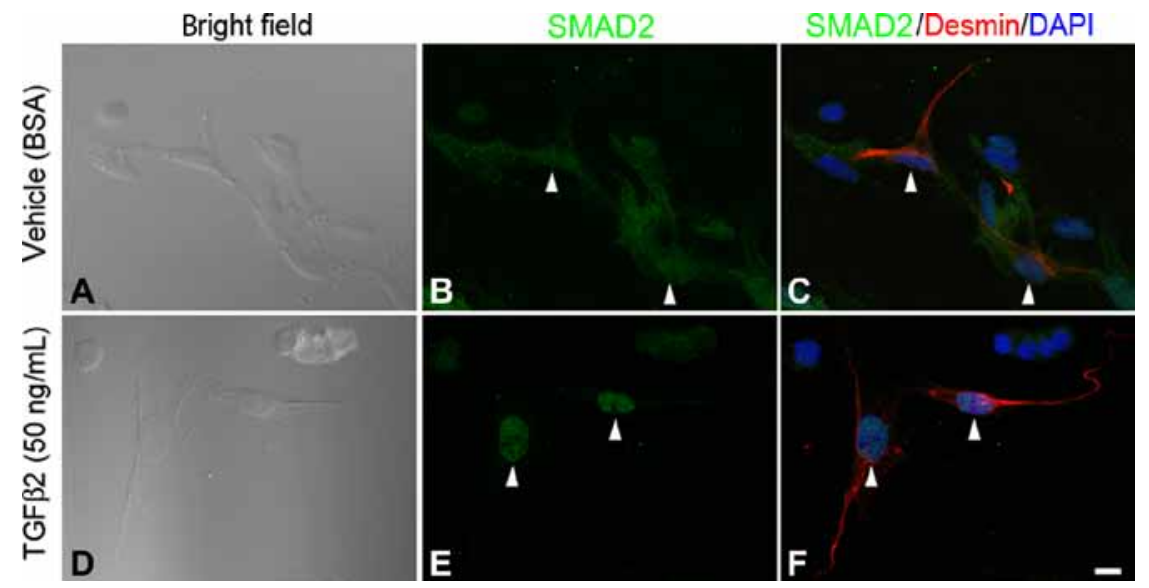

Figure 6

Immunocytochemistry of SMAD2 and desmin in anterior pituitary cells. Anterior pituitary cells from Wistar rats were treated with TGF $\beta 2$ ( $50 \mathrm{ng} / \mathrm{mL}$ ) or $0.1 \%$ BSA (vehicle) for $30 \mathrm{~min}$ and then stained for SMAD2 and desmin. The left panels show bright-field images of anterior pituitary cells $(a, d)$. The middle and right panels show SMAD2 staining and a merged image (SMAD2: green; desmin: red; DAPI: blue) respectively. Diffuse cytoplasmic staining of SMAD2 was seen in vehicle-treated desmin-immunopositive cells (pericytes: b, c); however, intense nuclear staining was seen in TGF $\beta 2$-treated desminimmunopositive cells (e, f). Arrowheads: nucleus of desmin-immunopositive cells. Bar: $10 \mu \mathrm{m}$. 

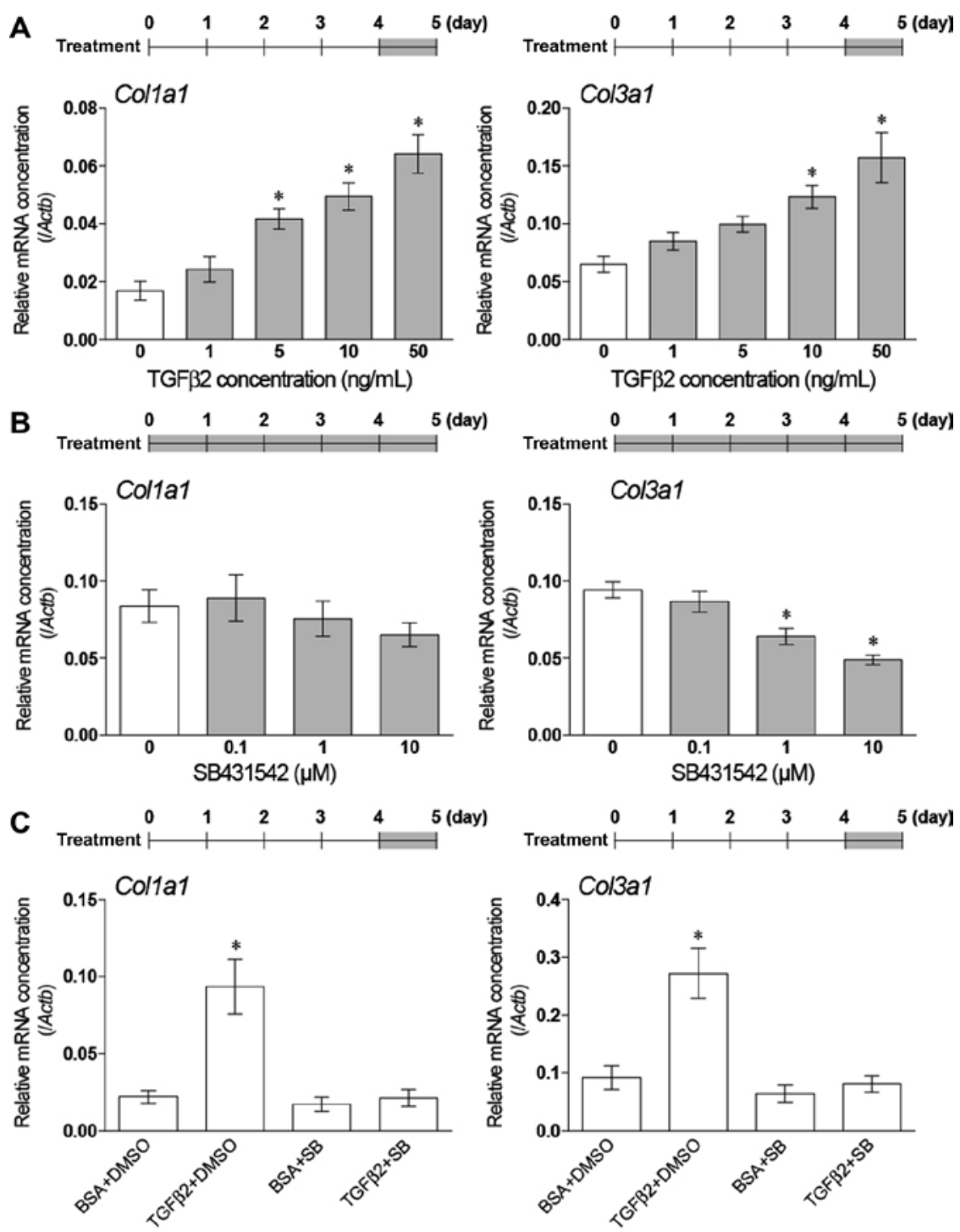

\section{Figure 7}

Relative mRNA concentrations of type I (Col1a1) and type III (Col3a1) collagens in cell aggregates treated with TGF $\beta 2$ and/or selective TGF $\beta$ receptor I inhibitor (SB431542) were evaluated by quantitative real-time PCR. Treatment protocols are indicated above the respective graphs. mRNA concentrations were normalized with $\beta$-actin (Actb) mRNA concentration. Anterior pituitary cells of Wistar rats were used. (A) Cell aggregates were treated with different concentrations of TGF $\beta 2$ ( $1-50 \mathrm{ng} / \mathrm{mL}$ ). TGF $\beta 2$ induced type I and type III collagen synthesis in a dose-dependent manner ( $n=4$, mean \pm s.E.M.). (B) Cell aggregates were treated with different concentrations of SB431542 $(0.1-10 \mu \mathrm{M})$. SB431542 decreased type III collagen synthesis in a dose-dependent manner; however, the effect on type I collagen synthesis was not significant $(n=6$, mean \pm S.E.M.). (C) Cell aggregates were treated with TGF $\beta 2$ (50 $\mathrm{ng} / \mathrm{mL}$ ) and SB431542 $(10 \mu \mathrm{M})$. BSA and DMSO were the vehicle control for TGF $\beta 2$ and SB431542 (SB) respectively. SB431542 attenuated TGF $\beta 2$ induced collagen synthesis $(n=6$, mean \pm S.E.M). $* P<0.05$ (Dunnett's test).
As shown in Fig. 3, the removal of folliculostellate cells reduced desmin-positive cells concomitantly with a reduction in desmin mRNA level. Desmin is expressed in pericytes in rat anterior pituitary gland (Fujiwara et al. 2010, Jindatip et al. 2013) and in cell aggregates (Supplementary Fig. 1, see section on supplementary data given at the end of this article). Thus, the present findings reveal a novel interaction between folliculostellate cells and pericytes in the gland. Pericytes are mural cells of capillaries and share a basement membrane with vascular endothelial cells (Shepro \& Morel 1993). Because pericytes are important collagenproducing cells in the gland (Fujiwara et al. 2010), removal of folliculostellate cells might influence collagen production in pericytes, resulting in the absence of collagen deposition. However, because pericytes exhibit cellular plasticity (Armulik et al. 2005, Birbrair et al. 2013), it is not clear whether the reductions in desmin mRNA and protein in folliculostellate cell-deficient cell aggregates are attributable to trans differentiation into another cell type that does not express desmin, to loss of pericytes, or to reduced proliferative activity in pericytes.

Cell-to-cell communication is generally mediated by paracrine factors and/or juxtacrine factors and by gap junction-mediated intercellular interaction. In rat anterior pituitary gland, folliculostellate cells and pericytes do not have direct contact because of the basement membrane between them (Inoue et al. 1999). We hypothesized that a paracrine factor mediates the interaction and thus focused on the TGF $\beta$ family. The TGF $\beta$ family is known as profibrotic growth factor and

Published by Bioscientifica Ltd. 


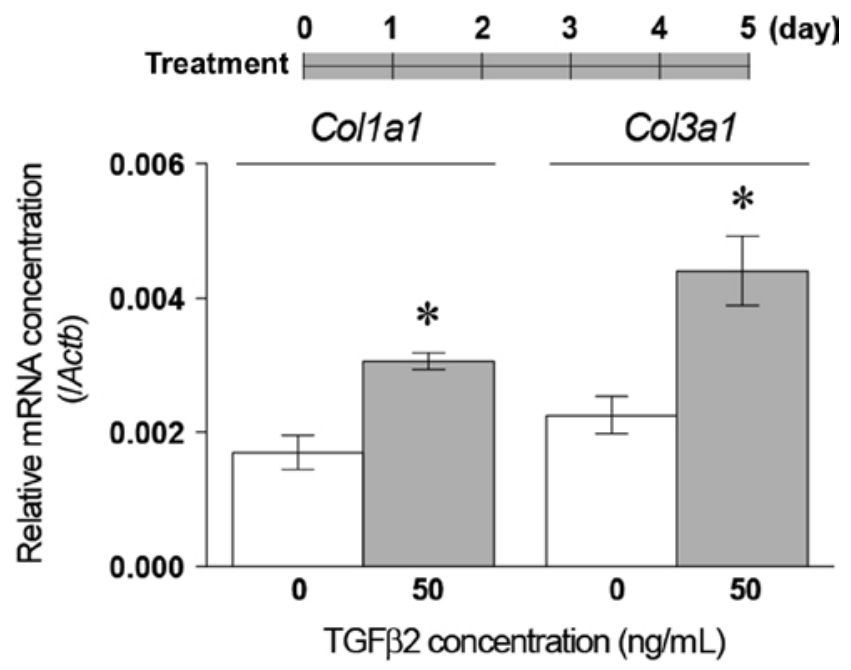

Figure 8

Relative mRNA concentrations of type I (Co/1a1) and type III (Co/3a1) collagens in folliculostellate cell-deficient cell aggregates treated with TGF $\beta 2$ evaluated by quantitative real-time PCR. Treatment protocol is indicated above the graph. mRNA concentrations were normalized with $\beta$-actin (Actb) mRNA concentration. Folliculostellate cell-deficient cell aggregates were treated with TGF $\beta 2(50 \mathrm{ng} / \mathrm{mL})$. TGF $\beta 2$ significantly increased type I and type III collagen synthesis $(n=4$, mean \pm S.E.M. $)$. $\star P<0.05$ (Student's $t$-test).

has three isoforms (TGF $\beta 1-3)$. The present RT-PCR analysis showed that all the three TGF $\beta$ isoforms were expressed in the gland (Fig. 4). Previous studies showed that TGF $\beta 1$ and TGF $\beta 3$ are expressed in lactotrophs (Burns \& Sarkar 1993, Hentges et al. 2000) and that they have opposing actions on estrogen-induced lactotroph proliferation (Tan et al. 1997, Hentges et al. 2000). In contrast, TGF $\beta 2$-expressing cells have not been identified in the gland, with the exception of one report showing TGF 2 expression in TtT/GF cells, known as the murine pituitary folliculostellate-like cell line (Renner et al. 2002). This study is the first to demonstrate that folliculostellate cells express TGF $\beta 2$ in normal rat anterior pituitary gland (Figs 4 and 5). Regarding the receptors, TGF $\beta$ receptors I and II were expressed in the gland, whereas TGF $\beta$ receptor III ( $\beta$-glycan), which is not associated with canonical TGF $\beta$ signal transduction, was undetectable (Fig. 4). TGF $\beta$ isoforms first bind to TGF $\beta$ receptor II, and the complex recruits TGF $\beta$ receptor I, which induces subsequent intracellular signal transduction, including phosphorylation and nuclear translocation of SMADs (for a review see Macias et al. 2015). The present in situ hybridization revealed that TGF $\beta$ receptor II was expressed in endothelial cells, pericytes, and parenchymal cells (Fig. 5). A study of parenchymal cells detected TGF $\beta$ receptor II in lactotrophs (De et al. 1996).
The present RT-PCR analysis detected transcripts of TGF $\beta$ receptor II in GFP-positive fractions (Fig. 4). Therefore, TGF $\beta$ receptor II-expressing parenchymal cells may include lactotrophs and folliculostellate cells. To confirm whether pericytes can transduce TGF $\beta$ signals, double immunocytochemistry for SMAD2 and desmin was performed. As shown in Fig. 6, immunoreactive SMAD2 was localized in the nuclei of pericytes when cultured anterior pituitary cells were in the presence of TGF $\beta 2$, indicating that TGF $\beta 2$ directly acts on pericytes through TGF $\beta$ receptors I and II.

TGF $\beta$ induces collagen synthesis in fibroblasts (Roberts et al. 1986). Thus, we examined whether TGF $\beta 2$ has a similar action on pericytes and found that TGF $\beta 2$ increased collagen synthesis in a dose-dependent manner and that TGF $\beta 2$ induced collagen synthesis was completely blocked by SB431542, a TGF $\beta$ receptor I inhibitor (Fig. 7A and C). These results suggest that canonical TGF $\beta$ signals in pericytes are associated with collagen gene regulation. We also showed that SB431542 significantly reduced type III collagen synthesis (Fig. 7B). These results suggest that endogenous TGF $\beta 2$ from folliculostellate cells affects collagen synthesis of pericytes in a 3D cell culture. Furthermore, reduction of collagen synthesis in folliculostellate cell-deficient cell aggregates was partially rescued by TGF $\beta 2$ treatment, which suggests that loss of TGF $\beta 2$ in folliculostellate cell-deficient cell aggregates reduced collagen synthesis. However, the collagen mRNA level could not be recovered to the level in aggregates containing folliculostellate cells; thus, an effect by a factor other than TGF $\beta 2$ cannot be excluded.

In sum, we demonstrated that TGF 22 -mediated interaction between folliculostellate cells and pericytes is important in collagen synthesis and deposition in rat anterior pituitary gland. In general, the functions of anterior pituitary cells are controlled by hormones from the hypothalamus and target organs. However, existing evidence indicates that surrounding cells and ECM also influence pituitary cell functions (Paez-Pereda et al. 2005, Le Tissier et al. 2012). Indeed, our recent study found that type I and III collagens act on folliculostellate cells to induce cell proliferation (Horiguchi et al. 2010) and small leucine-rich proteoglycan production (Syaidah et al. 2013). Past and present evidence, taken together, suggests the following explanation for folliculostellate cell-mediated cell and ECM interaction: 1) folliculostellate cells act on pericytes via TGF $\beta 2,2$ ) pericytes synthesize collagen in response to TGF $\beta 2$, and 3 ) deposited collagens affect folliculostellate cell functions. Thus, folliculostellate cell, pericyte, and collagen interactions are mutually interdependent rather than independent.

Published by Bioscientifica Ltd 
Furthermore, our recent study identified another cell-to-cell interaction between folliculostellate cells and gonadotrophs in rat anterior pituitary gland (Tsukada et al. 2014). Gonadotrophs produce the major basement membrane component laminin (Holck et al. 1987, Ramadhani et al. 2012). We showed that humoral factor from folliculostellate cells is required for the release of laminin from gonadotrophs (Tsukada et al. 2014). We also observed various laminin actions on folliculostellate cells, such as proliferation, migration, and gap junction formation, as well as production of ECM and matrix metalloproteinase (Horiguchi et al. 2010, 2011, 2012, Ilmiawati et al. 2012, Syaidah et al. 2013). Thus, folliculostellate cells, gonadotrophs, and laminin are also interdependent. These past and present findings reveal much about complex cell-to-cell and/or cell-to-ECM interactions in the anterior pituitary gland. Nevertheless, additional studies are needed if we are to understand fully the local interactions in the anterior pituitary.

\section{Supplementary data}

This is linked to the online version of the paper at http://dx.doi.org/10.1530/ JOE-16-0033.

\section{Declaration of interest}

The authors declare that there is no conflict of interest that could be perceived as prejudicing the impartiality of the research reported.

\section{Funding}

This work was partly supported by JSPS KAKENHI Grants (numbers 26460281 to $K F$ and 25860147 to T T), by promotional funds from the Keirin Race of the Japan Keirin Association, and by the Jichi Medical University Young Investigator Award from Jichi Medical University School of Medicine (to T T).

\section{Acknowledgments}

The authors thank K Inoue (Saitama University, Japan) for supplying the transgenic rats, T Nakamura (Hokkaido University, Japan) for supplying type I and type III collagen antibodies, Y Hanazono and T Abe (Jichi Medical University) for their support in fluorescence-activated cell sorting, Megumi Yatabe (Jichi Medical University, Japan) for her excellent technical assistance, and David Kipler, ELS (Supernatant Communications) for revising the language of the manuscript. The authors have no conflict of interest that might prejudice the impartiality of this research.

\section{References}

Allaerts W \& Vankelecom H 2005 History and perspectives of pituitary folliculo-stellate cell research. European Journal of Endocrinology 153 1-12. (doi:10.1530/eje.1.01949)
Armulik A, Abramsson A \& Betsholtz C 2005 Endothelial/pericyte interactions. Circulation Research 97 512-523. (doi:10.1161/ 01.RES.0000182903.16652.d7)

Azuma M, Tofrizal A, Maliza R, Batchuluun K, Ramadhani D, Syaidah R, Tsukada T, Fujiwara K, Kikuchi M, Yashiro T, et al. 2015 Maintenance of the extracellular matrix in rat anterior pituitary gland: identification of cells expressing tissue inhibitors of metalloproteinases. Acta Histochemica et Cytochemica 48 1-8. (doi:10.1267/ahc.14059)

Birbrair A, Zhang T, Wang Z-M, Messi ML, Mintz A \& Delbono O 2013 Type-1 pericytes participate in fibrous tissue deposition in aged skeletal muscle. American Journal of Physiology: Cell Physiology $\mathbf{3 0 5}$ C1098-C1113. (doi:10.1152/ajpcell.00171.2013)

Burns G \& Sarkar DK 1993 Transforming growth factor beta 1-like immunoreactivity in the pituitary gland of the rat: effect of estrogen. Endocrinology 133 1444-1449.

De A, Morgan TE, Speth RC, Boyadjieva N \& Sarkar DK 1996 Pituitary lactotrope expresses transforming growth factor beta (TGF beta) type II receptor mRNA and protein and contains 125I-TGF beta 1 binding sites. Journal of Endocrinology 149 19-27. (doi:10.1677/joe.0.1490019)

Fujiwara K, Maekawa F, Kikuchi M, Takigami S, Yada T \& Yashiro T 2007a Expression of retinaldehyde dehydrogenase (RALDH) 2 and RALDH3 but not RALDH1 in the developing anterior pituitary glands of rats. Cell and Tissue Research 328 129-135. (doi:10.1007/ s00441-006-0345-7)

Fujiwara K, Kikuchi M, Takigami S, Kouki T \& Yashiro T 2007b Expression of retinaldehyde dehydrogenase 1 in the anterior pituitary glands of adult rats. Cell and Tissue Research 329 321-327. (doi:10.1007/ s00441-007-0423-5)

Fujiwara K, Jindatip D, Kikuchi M \& Yashiro T 2010 In situ hybridization reveals that type I and III collagens are produced by pericytes in the anterior pituitary gland of rats. Cell and Tissue Research 342 491-495. (doi:10.1007/s00441-010-1078-1)

Gelse K, Pöschl E \& Aigner T 2003 Collagens - structure, function, and biosynthesis. Advanced Drug Delivery Reviews 55 1531-1546. (doi:10.1016/j.addr.2003.08.002)

Hagiwara Y, Ando A, Onoda Y, Matsui H, Chimoto E, Suda H \& Itoi E 2010 Expression patterns of collagen types I and III in the capsule of a rat knee contracture model. Journal of Orthopaedic Research $\mathbf{2 8}$ 315-321. (doi:10.1002/jor.20997)

Hamzah J, Jugold M, Kiessling F, Rigby P, Manzur M, Marti HH, Rabie T, Kaden S, Gröne HJ, Hämmerling GJ, et al. 2008 Vascular normalization in Rgs5-deficient tumours promotes immune destruction. Nature 453 410-414. (doi:10.1038/nature06868)

Hentges S, Pastorcic M, De A, Boyadjieva N \& Sarkar DK 2000 Opposing actions of two transforming growth factor-beta isoforms on pituitary lactotropic cell proliferation. Endocrinology 141 1528-1535. (doi:10.1210/en.141.4.1528)

Holck S, Albrechtsen R \& Wewer UM 1987 Laminin in the anterior pituitary gland of the rat. Laminin in the gonadotrophic cells correlates with their functional state. Laboratory Investigation: A Journal of Technical Methods and Pathology 56 481-488.

Horiguchi K, Fujiwara K, Kouki T, Kikuchi M \& Yashiro T 2008 Immunohistochemistry of connexin 43 throughout anterior pituitary gland in a transgenic rat with green fluorescent protein-expressing folliculo-stellate cells. Anatomical Science International 83 256-260. (doi:10.1111/j.1447-073x.2008.00239.x)

Horiguchi K, Kikuchi M, Kusumoto K, Fujiwara K, Kouki T, Kawanishi K \& Yashiro T 2010 Living-cell imaging of transgenic rat anterior pituitary cells in primary culture reveals novel characteristics of folliculo-stellate cells. Journal of Endocrinology 204 115-123. (doi:10.1677/JOE-09-0333)

Horiguchi K, Kouki T, Fujiwara K, Kikuchi M \& Yashiro T 2011 The extracellular matrix component laminin promotes gap junction formation in the rat anterior pituitary gland. Journal of Endocrinology 208 225-232. (doi:10.1677/JOE-10-0297) 
Horiguchi K, Kouki T, Fujiwara K, Tsukada T, Ly F, Kikuchi M \& Yashiro T 2012 Expression of the proteoglycan syndecan-4 and the mechanism by which it mediates stress fiber formation in folliculostellate cells in the rat anterior pituitary gland. Journal of Endocrinology 214 199-206. (doi:10.1530/JOE-12-0156)

Hosoya O \& Watanabe YG 1997 Possible involvement of folliculostellate cells in the differentiation of muscle fibers during monolayer culture of pituitary cells. Zoological Science 14 141-145. (doi:10.2108/ zsj.14.141)

Hwang NS, Zhang C, Hwang Y-S \& Varghese S 2009 Mesenchymal stem cell differentiation and roles in regenerative medicine. Wiley Interdisciplinary Reviews: Systems Biology and Medicine 1 97-106. (doi:10.1002/wsbm.26)

Ilmiawati C, Horiguchi K, Fujiwara K \& Yashiro T 2012 Matrix metalloproteinase-9 expression in folliculostellate cells of rat anterior pituitary gland. Journal of Endocrinology 212 363-370. (doi:10.1530/ JOE-11-0433)

Inoue K, Couch EF, Takano K \& Ogawa S 1999 The structure and function of folliculo-stellate cells in the anterior pituitary gland. Archives of Histology and Cytology 62 205-218. (doi:10.1679/aohc.62.205)

Itakura E, Odaira K, Yokoyama K, Osuna M, Hara T \& Inoue K 2007 Generation of transgenic rats expressing green fluorescent protein in S-100beta-producing pituitary folliculo-stellate cells and brain astrocytes. Endocrinology 148 1518-1523. (doi:10.1210/en.2006-1390)

Jindatip D, Fujiwara K, Horiguchi K, Tsukada T, Kouki T \& Yashiro T 2013 Changes in fine structure of pericytes and novel desminimmunopositive perivascular cells during postnatal development in rat anterior pituitary gland. Anatomical Science International $\mathbf{8 8}$ 196-203. (doi:10.1007/s12565-013-0180-3)

Kaidzu S, Noda T, Tane N \& Yashiro 2000 Collagen synthesis by rat anterior pituitary cells in vivo and in vitro. Acta Histochemica et Cytochemica 33 81-87. (doi:10.1267/ahc.33.81)

Kuchenbauer F, Hopfner U, Stalla J, Arzt E, Stalla GK \& Páez-Pereda M 2001 Extracellular matrix components regulate ACTH production and proliferation in corticotroph tumor cells. Molecular and Cellular Endocrinology 175 141-148. (doi:10.1016/S0303-7207(01)00390-2)

Le Tissier PR, Hodson DJ, Lafont C, Fontanaud P, Schaeffer M \& Mollard P 2012 Anterior pituitary cell networks. Frontiers in Neuroendocrinology 33 252-266. (doi:10.1016/j.yfrne.2012.08.002)

Macias MJ, Martin-Malpartida P \& Massagué J 2015 Structural determinants of Smad function in TGF- $\beta$ signaling. Trends in Biochemical Sciences 40 296-308. (doi:10.1016/j.tibs.2015.03.012)

Narimatsu M, Samavarchi-Tehrani P, Varelas X \& Wrana JL 2015 Distinct polarity cues direct Taz/Yap and TGFb receptor localization to differentially control TGFb-induced Smad ssignaling. Developmental Cell 32 652-656. (doi:10.1016/j.devcel.2015.02.019)
Paez-Pereda M, Kuchenbauer F, Arzt E \& Stalla GK 2005 Regulation of pituitary hormones and cell proliferation by components of the extracellular matrix. Brazilian Journal of Medical and Biological Research 38 1487-1494. (doi:10.1590/S0100-879X2005001000005)

Perez-Castro C, Renner U, Haedo MR, Stalla GK \& Arzt E 2012 Cellular and molecular specificity of pituitary gland physiology. Physiological Reviews 92 1-38. (doi:10.1152/physrev.00003.2011)

Ramadhani D, Tsukada T, Fujiwara K, Horiguchi K, Kikuchi M \& Yashiro T 2012 Laminin isoforms and laminin-producing cells in rat anterior pituitary. Acta Histochemica et Cytochemica 45 309-315. (doi:10.1267/ ahc.12028)

Renner U, Lohrer P, Schaaf L, Feirer M, Schmitt K, Onofri C, Arzt E \& Stalla GK 2002 Transforming growth factor-beta stimulates vascular endothelial growth factor production by folliculostellate pituitary cells. Endocrinology 143 3759-3765. (doi:10.1210/en.2002-220283)

Roberts AB, Sporn MB, Assoian RK, Smith JM, Roche NS, Wakefield LM, Heine UI, Liotta LA, Falanga V \& Kehrl JH 1986 Transforming growth factor type beta: rapid induction of fibrosis and angiogenesis in vivo and stimulation of collagen formation in vitro. PNAS 83 4167-4171. (doi:10.1073/pnas.83.12.4167)

Shepro D \& Morel NM 1993 Pericyte physiology. FASEB Journal 7 1031-1038.

Syaidah R, Horiguchi K, Fujiwara K, Tsukada T, Kikuchi M \& Yashiro T 2013 Laminin and collagen modulate expression of the small leucine-rich proteoglycan fibromodulin in rat anterior pituitary gland. Cell and Tissue Research 354 633-638. (doi:10.1007/ s00441-013-1698-3)

Tan SK, Wang FF, Pu HF \& Liu TC 1997 Differential effect of age on transforming growth factor-beta 1 inhibition of prolactin gene expression versus secretion in rat anterior pituitary cells. Endocrinology 138 878-885. (doi:10.1210/en.138.3.878)

Toral C, Solano-Agama C, Reyes-Márquez B, Sabanero M, Talamás P, González del Pliego M \& Mendoza-Garrido ME 2007 Role of extracellular matrix-cell interaction and epidermal growth factor (EGF) on EGF-receptors and actin cytoskeleton arrangement in infantile pituitary cells. Cell and Tissue Research 327 143-153. (doi:10.1007/s00441-006-0248-7)

Tsukada T, Kouki T, Fujiwara K, Ramadhani D, Horiguchi K, Kikuchi M \& Yashiro T 2013 Reassembly of anterior pituitary organization by hanging drop three-dimensional cell culture. Acta Histochemica et Cytochemica 46 121-127. (doi:10.1267/ahc.13015)

Tsukada T, Fujiwara K, Horiguchi K, Azuma M, Ramadhani D, Tofrizal A, Batchuluun K, Maliza R, Syaidah R, Kikuchi M \& Yashiro 2014 Folliculostellate cells are required for laminin release from gonadotrophs in rat anterior pituitary. Acta Histochemica et Cytochemica 47 239-245. (doi:10.1267/ahc.14036)

Received in final form 3 March 2016

Accepted 7 March 2016

Accepted Preprint published online 8 March 2016 http://joe.endocrinology-journals.org

DOI: $10.1530 / J O E-16-0033$
() 2016 Society for Endocrinology Printed in Great Britain
Published by Bioscientifica Ltd 